Polgári Szemle, 16. évf. 1-3. szám, 2020, 7-9., DOI: 10.24307/psz.2020.0701

\title{
Történelmi siker után vagyunk, vagy egy permanens megújulás képességének kapujában?
}

\section{Fôszerkesztôi beköszöntô}

\author{
Journal of Economic Literature (JEL) kódok: B20, N01 \\ Kulcsszavak: gazdaságpolitika, új állampénzügyi rendszer, Covid-19, Magyarország
}

A reneszánsz virágkorának világszerte legismertebb, legnépszerúbb és legszubjektívebb francia költôje, François Villon találóan írta egyik balladájában, „s az évek szálltak, mint a percek", utalva ezzel az élet gyors elmúlására. E megfogalmazás a tartalmas életet élôk, vagy legalábbis az életet élvezôk s a reményteli, boldog korszakok esetében valóban így érzékelhetô, ám ha a Jóisten kegyes hozzánk, a lendület a sikeres folytatáshoz jó ideig nem csökken.

A magyar gazdaságtörténet ugyan nem bôvelkedik a sikeres kurzusokban, ám az a kevés, ami van, ami beteljesedett, bizony figyelmet érdemel. Figyelmet érdemel a függetlenségét kiteljesítô, gazdaságát megerôsítô dualizmus korszaka, az állam hathatós közrehatásával felépített magyar kapitalizmus, és egy nagyot ugorva, hiszen ezen fél évszázadot követô 20. századot lényegében elveszítettük, az elmúlt tíz év újjászervezett magyar gazdasága, a magyar modell.

Az elsố világháborút követố területi, gazdasági és lélekszámbeli veszteségek, a második világháború pokla, majd a szovjet megszállás s a vele járó politikai és gazdasági berendezkedés nem feltétlenül a legsikeresebb korszakok voltak Magyarország számára. Mint ahogy a tervgazdasági rendszer felbomlását követô neoliberális piacgazdaság a maga nyers mivoltával, átmenetnélküliségével is inkább rombolt, mint épített. Sôt pontosítsunk, többet rombolt, mint amennyit épített. Egy évszázadot kellett várni ahhoz, hogy a magyar gazdaság újra erôre kapjon, saját erejéból fejlôdésnek induljon, társadalma pedig gyarapodjon. Anyagiakban és lélekben egyaránt.

Az ezredfordulón volt ugyan egy rövid, „szívet melengetô korszak”, hogy Matolcsy Györgyöt idézzem, a Széchenyi Nemzeti Fejlesztési Terv sikerperiódusára asszociálva, ám a sors akkor, 2002-tôl nem lett hozzánk kegyes. A hatalomra kerülô liberális kormányok fiskális alkoholizmusa, a társadalom és a hazai gazdaság felé érzéketlen jegybanki politika, majd az „i-re a pont”, a 2007-2008-as világgazdasági válság hazánkra vetülô 
árnyai gazdasági pangást, munkanélküliséget, eladósodottságot, külgazdasági és külpolitikai kiszolgáltatottságot hoztak.

2010-tôl azonban a politikai, majd a gazdasági térben változások vették kezdetüket. Az Alaptörvény közpénzügyi fejezetén és a polgári értékrend szellemiségén felépülő közpénzügyi tárgyú törvények, a költségvetési és adóellenőrzés jogköreinek és módszertanának kiteljesedése, a közteherviselés intézményének érvényesítése, a családtámogatási rendszer kibóvítése, majd 2013-tól a monetáris rendszerváltozás makrogazdasági és társadalmi hatásai megerôsítették Magyarországot. Csökkent az adósság, az infláció, nôttek a keresetek, a jövedelmek, ezzel együtt az ország és a társadalom magabiztossága. Sarjadnak azok a tudományos eszmék, amelyek a magyar modell gazdasági és társadalmi logikáját tudományosan is leképezik. A Bokros- és Gyurcsány-éra szellemisége által uralt évtizedek után a megszorítások helyébe a fejlesztések, az általános gyarapodás lépett. A családok, önkormányzatok, hazai vállalkozások megsarcolására alapozó liberális gazdaságpolitika kudarcot vallott, bizalmat vesztett, mint ahogy az adóemelések és támogatásmegvonások „szakszerúségét” hirdetô tudományos körök sem állnak nyerésre. Nincs persze még minden a rendjén a tudományos életben, annak ellenére sem, hogy Magyar Tudományos Akadémián változások kezdődnek, hiszen a tudományos szektor középmezónye, fôleg a társadalomtudományi egyetemi képzés tartalma bizony tíz év alatt jottányit sem változott. Ha négy évszázaddal az európai könyvnyomtatás elterjedése után Vörösmarty feltehette a kérdést, miszerint: „Ment-e a könyvek által a világ elébb?”, bizony nekünk is jó okunk van a kétkedésre, s jó okunk van a változások továbbvitelére. Mindaddig, amíg egy ország szellemi elitje nem képes a társadalmi, gazdasági formációjához hiteles forrást, szellemi katasztert és tudományos hátteret „kitermelni”, „létrehozni”, addig bizony problémák vannak, s a társadalmi, gazdasági és a közjogi értelemben vett folytatáshoz a feltételek nem adottak, hiába a politikai szándék.

Mindeközben, s hogy újra Villon szellemét megidézzem, A haláltánc-balladáját, „pestis-csengókkel jött a dögvész”. 2020. év elején a növekedési pályánk csúcsán egy olyan világjárvány s annak gazdasági hatásai vetnek vissza bennünket, amely kénytelen-kelletlen távol tartja a munkaerőt a munkahelyektől, ami által csökken a termelés, a jövedelem, bár a termékekre, szolgáltatásokra sincs olyan mértékú szükség, mint a konjunktúra idôszakában. Csökken-e, csökkenhet-e ezáltal a lendületünk, a növekedésre és sikerekre szocializálódott világképünk összébb eshet-e? - merülhet fel a kérdés a nyájas olvasóban.

A növekedési pályánk zenitjében, kerülendő a gazdaságunk túlfútöttségéből adódó esetleges problémákat, kerülendô a növekedési ciklusunk kifulladását, egyre erôsebben foglalkoztatott bennünket a versenyképesség, a fejlődésképességünk fenntartása. Most, a járvány gazdasági hatásait érzékelve, még jobban elótérbe kerülnek a 21. század új kihívásai, a regionális szemlélet, vagyis a globalizáció világhódító jellegének ellensúlyozása, a digitalizáció, a pénz forradalma, hagyományos szerepének és megjelenési módjainak megváltozása, a környezetet jobban kímélố zöldgazdaság térnyerése, az átalakuló fogyasztói és társadalmi szokások, az életvitel s talán ezekból adódóan a társadalmak elöregedése, a családvállalásról való lemondás tömegesedése. Ezek a kihívások, 
és ha ugyan el is múltak azok az évek, amikor ezekkel még kevésbé kellett foglalkoznunk, mára e követelményeknek való megfelelés a körmünkre égett. Lépéskényszerbe is kerültünk, hiszen a növekedési csapda kerülése mellett, a járványhelyzet utáni új világrend új kihívásaira is reagálni kell a magyar gazdaság- és társadalompolitikának, hogy mind a társadalom felé, mind a külsố versenytársaink vonatkozásában megálljuk a helyünket, versenyképesek, sikeresek maradhassunk.

A válság „kitömött” állapotban, erônk teljében ért el bennünket. Nem a kormány, illetve a jegybank politikája miatt emelkedik a munkanélküliség, növekszik átmenetileg a költségvetési hiány, hanem külsô, előre nem látható okok következtében. Más a helyzet tehát, mint 2008-ban, amikor a koncepciótlanul túlköltekezô liberális kormányok állami, vállalati és családi szinteken adósságcsapdába hajszoltak bennünket. A kormány és a jegybank összehangolt intézkedései, de fôleg az eddigi jelentôs gazdasági potenciál bázisán most van erố a védekezésre, s lesz forrás a konszolidációra is. De valahogy többról lesz már szó, mint ugyanarra a gazdasági pályára visszaállni, amely 2020. év elejéig jellemzett bennünket. Még jobban felértékelődik majd a tudás szerepe, a hatékony gazdálkodásé, miáltal a gazdaságpolitika, a vállalatok múködése, benne a munkaerô szemlélete, munkához való hozzáállása más lesz. Felgyorsul a világ. Még jobban, mint valaha. Az ennek való megfelelés pedig a felsôoktatás színvonalának, tartalmának megváltozása nélkül aligha lehetséges.

Ezt az új világrendet, annak fôbb ismérveit, már formálódó jegyeit állítottuk a 16. évfolyamunk 1-3. magyar lapszámának fókuszába. Szerzôink a koronavírus-járványt s annak gazdasági, társadalmi hatásait exponálják, a Magyar Nemzeti Bank elnökétől a fiatal kutatókig terjedóen. Teljesítjük továbbra is tudományos küldetésünket, vagyis a megváltozó világ tudományos elemzését tárjuk olvasóink elé.

Érdemes Polgári Szemlét olvasni!

Prof. dr. Lentner Csaba egyetemi tanár

a Polgári Szemle fôszerkesztôje 